\title{
NOTES ON SOME FUSARIUM AND CYLINDROCARPON ON DIPTEROCARPACEAE OF INDONESIA*
}

\author{
CLAIRE ELOUARD \\ Laboratory of Botany and Forestry \\ University of P. Sabatier, 39 Allees J. Guesde \\ 31000 Toulouse, France
}

\begin{abstract}
Six species of pathogenic fungi belonging to the genera Fusarium (Fusarium sacchari var. sacchari, $F$. moniliforme, F. oxysporum, F. spl, F. sp2) and Cylindrocarpon (Cylindrocarpon destructans) on seeds, seedlings and saplings of Dipterocarpaceae in Sumatra and West Java were identified.
\end{abstract}

\section{INTRODUCTION}

The trees of the Dipterocarpaceae family fill a prominent place in the Southeast Asian Tropical Forests as most of the species are used as timber trees or source of secondary products (e.g. resin "damar"). Their economic value is therefore of high interest to the local population and other countries (Symington 1974, Ashton 1982).

Up to the present, the exploitation of these forests consists of extracting timber from natural stands or at a lesser extent, in traditional management of agroforestry systems (Torquebiau 1984, Michon 1985). The possible fungal infections of these trees have been taken into account as debilitating factor of production.

During researches devoted to the Dipterccarp pathology, fungal attacks on seeds, seedlings and saplings have been observed frequently. They seem to be able to induce important damages in young stands and nurseries. Fungi and their damages were observed in several places in West Java and Sumatra (Figure 1). Most of them belong to the imperfect genera Fusarium and Cylindrocarpon (Tuberculariaceae).

* This study was conducted as part of a doctoral dissertation research under the supervision of Prof. G. Durrieu of Laboratory of Botany and Forestry, University of P. Sabatier, through the Tropical Forest Biology Programme of SEAMEO-BIOTROP. 


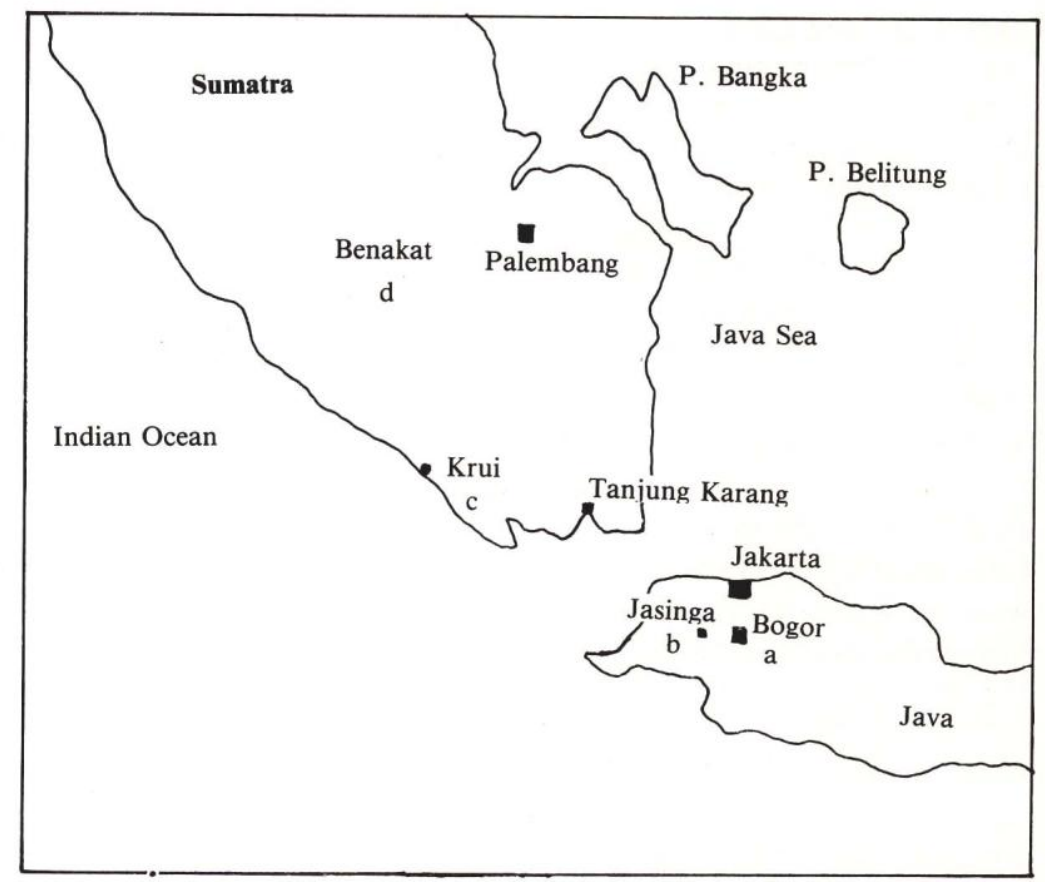

Figure 1. Location of study sites

\section{MATERIALS AND METHODS}

The pathogens were isolated from diseased organs (roots, collar, stem, twigs, leaves) and cultivated on Potato-Dextrose-Agar (PDA) in petri dishes, at room temperature (26 $32^{\circ} \mathrm{C}$ ). Inoculation experiments were performed on seedlings to confirm the virulence of the isolated strains. The species identification were based on recent literature (Booth 1971, Barnett \& Hunter 1972, Renard et al. 1972, Nirem-berg 1976) and was checked by Dr. M.F. Roquebert of Museum d' Histoire Naturelle Laboratoire de Cryptogamie, Paris.

\section{RESULTS AND DISCUSSION}

Among the pathogens isolated on Dipterocarps were different species of the genera Fusarium (i.e. F. sacchari var. sacchari, F. moniliforme and F. oxysporum) and Cylindrocarpon (i.e. C. destructans). Among the associated fungi which can 
be considered as secondary parasites were Pestalotia, Cylindrocladium, Nigrospora and Marasmius.

\section{Fusarium sacchari (Bull.) w, Gams. var. sacchari}

\section{Hosts}

Vatica pauciflora (Korth.) Bl.

This species was used to prevent fermentation of Palm Wine. The parasite was isolated from a sapling of about $70 \mathrm{~cm}$ height.

Shorea seminis (De Vriese) Sloot.

The fruits are used in Borneo as source of illipe butter (Ashton 1982). The hosts were about 2 years old and measured 20 to $30 \mathrm{~cm}$ in height.

\section{Shorea leprosula Miq.}

This Dipterocarp tree is one of the main sources of timber classified as light red Meranti (Symington 1974). Hosts were saplings of about one year old and 10-25 cm'in height. Both of these hosts came from the experimental plantation of Cikarawang of Bogor Agricultural University, Darmaga, Bogor, West Java (Figure la).

\section{Symptoms of the disease observed in the field (Figures $2 \& 3$ )}

Defoliation and weathering of saplings of Vatica pauciflora.

On Shorea seminis, beige-coloured spots delimited by a brown line, at first at the apex of leaves and later on covering the whole leaf surface, leading to its fall; at the base of the twig, necrosis could be observed; the bark of both collars and roots were necrosed and became dark; some of the plants were dry from root to apex.

Some Shorea leprosula were dry and dead, with darkish bark, cambium of collars and roots. Necrosis could be observed at the base of twigs. Alive plants have cracked collar's bark and darkish roots; leaves have brown spots, beginning from the extremity and later on covering the whole surface.

\section{Description of the pathogen (Figure 4)}

This Fusarium was isolated from the cambium of the branch of $V$. pauciflora and from leaves, twigs, collars and roots of S. seminis. The pigmentation of the medium was brown to vinaceous.

The mycelium was cream-coloured, pink to violet, aerial, cottony to fibrous. The growth rate was $6.8 \mathrm{~cm}$ after 4 days (Figure 5).

Microconidia were initially formed by simple phialides, and further more by branched conidiophores ended by polyphialides. The older the culture, the more 


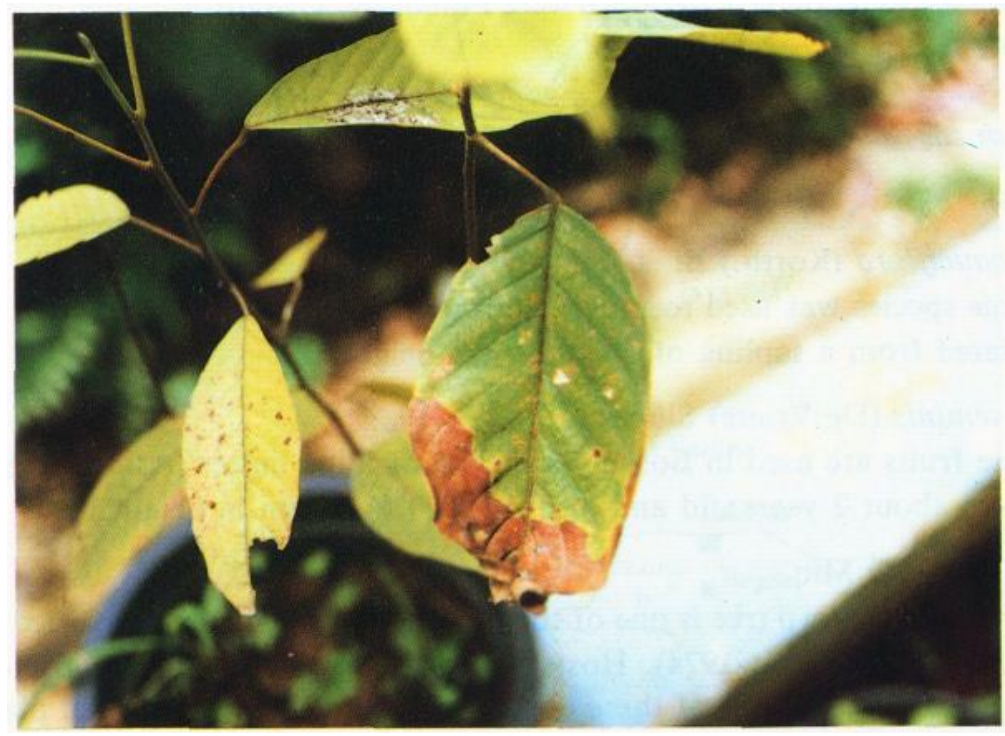

Figure 2. Spots on leaves of Shorea seminis caused by Fusarium sacchari var. sacchari

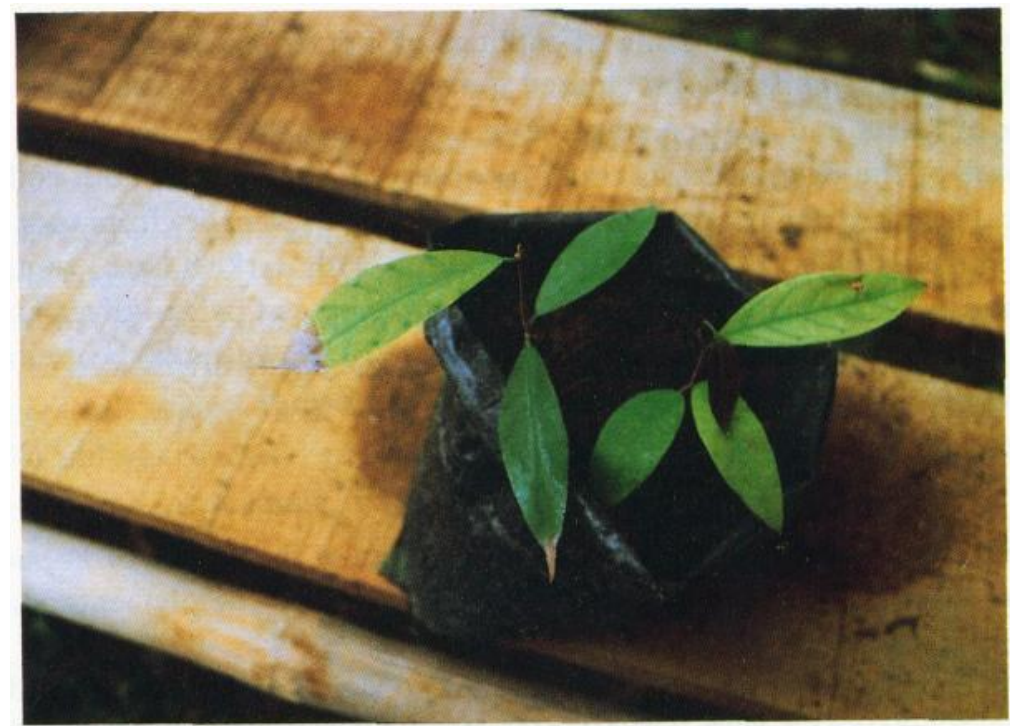

Figure 3. Vatica pauciflora inoculated with Fusarium sacchari var. sacchari 


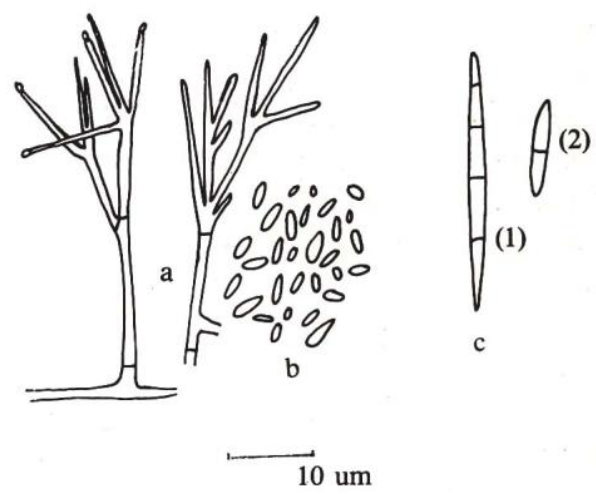

a. polyphialides

b. microconidia

c. macroconidia (1) mature (2) immature

Figure 4. Fusarium sacchari var. sacchari

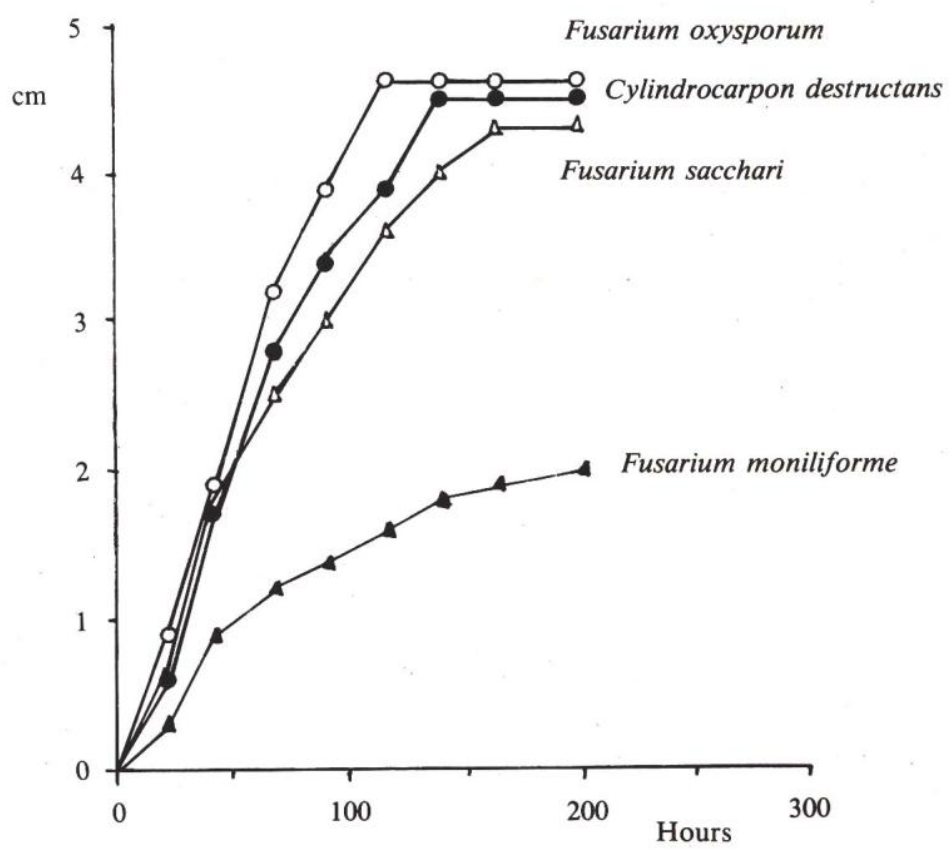

Figure 5. Growth rate of the fungi 
complex is the organization of conidiophores. Microconidia were oval to clavate, one-celled, and measured 3 - 10 x 1-3 um.

More often, there was no macroconidia in culture, or only few in number. Macroconidia were formed by simple phialides, generally straight, 3 to 6 septate, and measured 6-55 x 1.7-2.4 um.

No mycelial and conidial chlamydospores were observed.

\section{Associated fungi}

Two Marasmius species were associated with $F$. sacchari var. sacchari:

- M. equicrinis: it developed rhizomorphs like long black hairs, on which there were small carphophores (2-8 mm of diameter) on twigs, branches and leaves of hosts.

- Marasmius sp. developed white himanthium on twigs, branches and leaves.

Fusarium monitiforme Scheld. sensu Wollenw. et Reinking $=$ F. verticilloides (Sacc.) Niremberg Comb. Nov.

\section{Hosts}

Shorea javanica K. \& V.

This Shorea species has been exploited in agroforestry systems for about 150 years by local population in the Province of Lampung, South Sumatra (Figure Ic). Trees produce a resin ("damar") which is exported to Europe and America for the production of varnish, linoleum and paint. The trees were tapped and the resin was collected every month (Torquebiau 1984).

The parasite was collected on saplings of S. javanica of about $1 \mathrm{~m}$ to $1.5 \mathrm{~m}$ height and one to two years old.

\section{Symptoms of the disease observed in the field}

Defoliation and weathering of the plant; the bark of twigs and roots were black and the cambium was dry.

\section{Description of pathogens (Figure 6)}

This Fusarium was isolated from twigs and roots. The pigmentation of the medium was brown to violet.

The mycelium was cream-coloured, pink to violet, violet-grey; at first, appearing like a small cushion and later on becoming aerial, cottony to fibrous. The growth rate after 4 days was $2.2 \mathrm{~cm}$ (Figure 5).

Microconidiophores were simple, lateral to the hyphae and measured $27-54 \mathrm{x}$ 1 - $5 \mathrm{um}$. Microconidia were in chains and measured $5-17$ × 2-4 cm; they were 

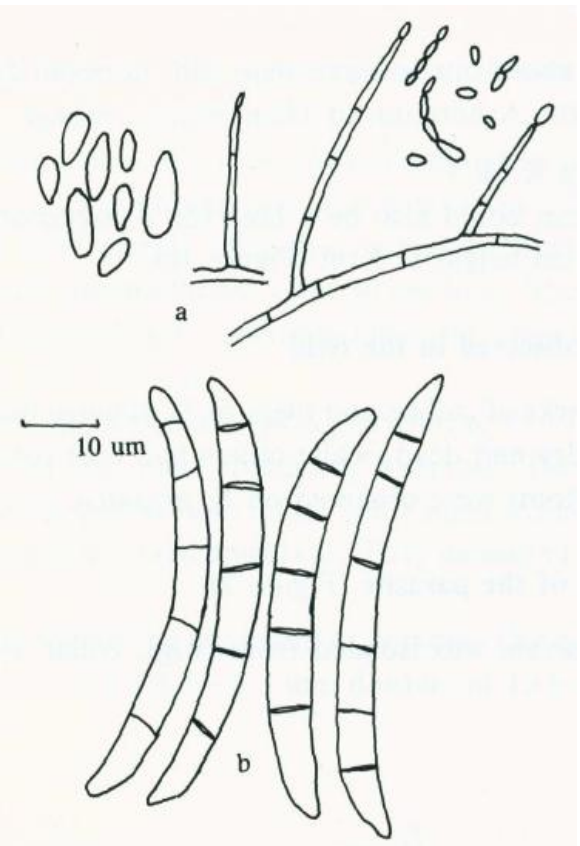

a. microconidiophores and microconidia

b. macroconidia

Figure 6. Fusarium moniliforme

one-celled, clavate to oval, sometimes with the basal cell lightly flattened.

Macroconidiophores were lateral branches of hyphae. Macroconidia were curved, with a flat basal cell and sometimes a sharp apical cell. They were 3-8 septate when mature and measured 40-72 x 4-5 um and seldom produced in culture.

No mycelial and conidial chlamydospores were observed.

\section{Associated fungi}

Two parasites were found associated with Fusarium moniliforme: Cylindrocladium sp. from collar and Pestalotia sp. from leaves with symptoms of beige spots. These two fungi were secondary parasites.

\section{Fusarium oxysporum Schlecht.}

\section{Hosts}

Shorea pinanga Scheff.

The fruits of S. pinanga were used as illipe-nuts. The pathogen was collected 
on saplings of about one to three years old, in population under an adult tree of $S$. pinanga at the Arboretum of Haurbentes, Jasinga, West Java (Figure 1b).

Shorea javanica K. \& V.

This species could also be a host for $F$. oxysporum. It was isolated from saplings of $60 \mathrm{~cm}$ height at Krui (Figure 1c).

\section{Symptoms observed in the field}

Roots, barks of collars and twigs of $S$. pinanga became darkish; some of the saplings were dry and dead, while others had root rot. No symptoms were observed on S. javanica.

\section{Description of the parasite (Figure 7)}

This Fusarium was isolated from twigs, collar and roots of saplings of S.

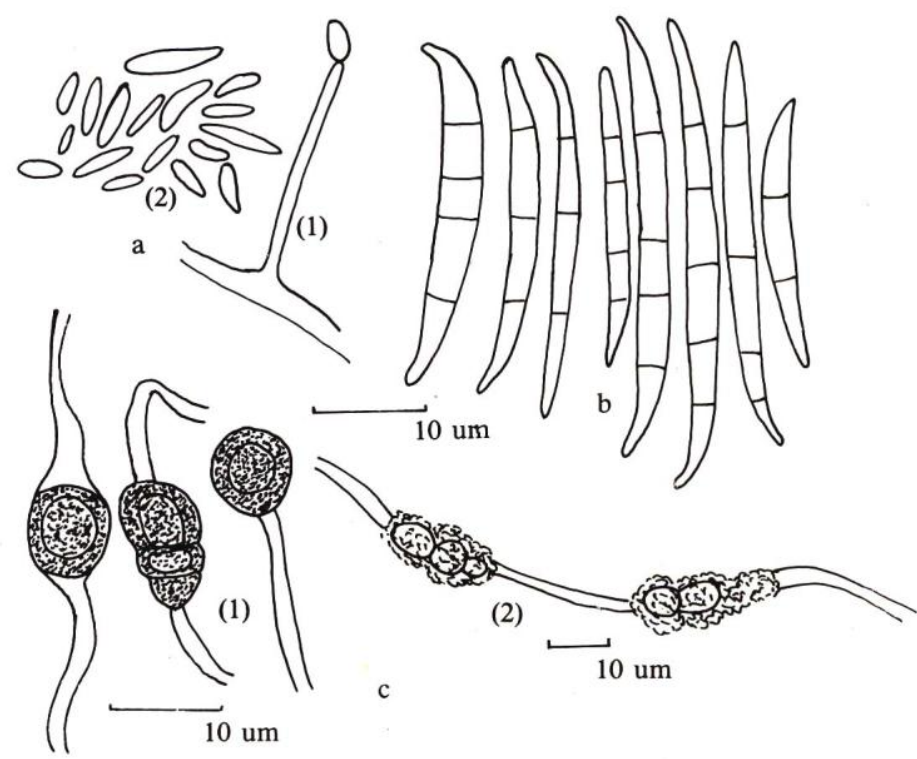
a. microconidiophore and microconidia
b. macroconidia
c. chlamydospores (1) smooth wall, (2) rough wall

Figure 7. Fusarium oxysporum 
pinanga and from twig of 5. javanica. The pigmentation of the medium was brown to violet.

The mycelium was cream-coloured, violet, like a small cushion at the beginning, aerial and cottony when older. The growth rate after 4 days was $5.2 \mathrm{~cm}$ (Figure 3).

Microconidiophores were simple phialides, lateral to hyphae, measuring 7-9 $\mathrm{x}$ 1-2 um, or branched conidiophores, until $30 \mathrm{um}$ long. Microconidia were variable in form, oval to ellipsoid and sometimes allantoid; they were one-celled and measured 4.7-14.4 x 1.5-4.7 um.

Macroconidiophores were lateral to hyphae, measuring $10-12 \times 1-1.5 \mathrm{um}$. Macroconidia were 3 to 5 septate, most frequently 3 septate. They were straight to lightly curved generally sharped at both ends. Some macroconidia had a pedi-form basal cell and a hooked and curved apical cell. They measured 16 - 44( - 80) x $24.5 \mathrm{um}$.

Chlamydospores were formed by mycelium or conidia. The mycelial chlamy-dospores were simple, of 7.7 - 8.9 x 6.5 - 8.3 um, double, of 10.6 x 6.5 um, both smooth and rough walled.

\section{Fusarium sp.l}

\section{Hosts}

\section{Shorea pinanga Scheff.}

This Fusarium sp. was collected on saplings of about 2 years old and $40 \mathrm{~cm}$ to $1 \mathrm{~m}$ in height in the nursery of BIOTROP, Bogor; seeds were previously collected in the Arboretum of Haurbentes (Figures la and b).

\section{Symptoms observed in the field}

Red-brown spots developed on leaves with a grey-coloured powder on the upper surface; spots appeared at the apex of leaves and were delimited by a red line; more often, young leaves were necrosed first and then spots came into sight. Development of spots on leaves led to necrosis and death of cells, and later on leaves fell. On twigs, cankers appeared and bark became darkish. On collars and roots, the pathogen caused dry rot, and collar's bark became darkish.

The propagation was not aerial but by the vascular system. Healthy leaves were wrapped with pieces of cellophane to avoid possible aerial contamination. Spots appeared on these wrapped leaves as well as on the unwrapped ones. The proga-gation then seems to be internal, by vessels. 


\section{Description of the pathogen (Figure 8)}

This Fusarium was isolated from leaves, twigs, collars and roots of S. pinanga. No pigmentation of the medium was observed.

The mycelium was cream-coloured to violet, like a small cushion. The growth rate was $5 \mathrm{~cm}$ after 4 days (Figure 5).

Microconidia were initially formed by long conidiophores of 45 - 62 x 1.2-1.8 um. Microconidia were oval, cylindrical, allantoid, one-celled, and measured 1.8-17 x 1.2-3.7 um.

Macroconidia were formed by simple phialides or simple conidiophores, $7-59 \mathrm{x}$ 1.2-1.5 um. Straight to curved, fusiform, they were 2 to 6 septate, and measured 14-41 x 1.8-5.4 um.

Chlamydospores were simple, $8.9 \times 6.5$ um, double, $12.4 \times 7.1$ um intercalary in mycelium or at the apex of hyphae.

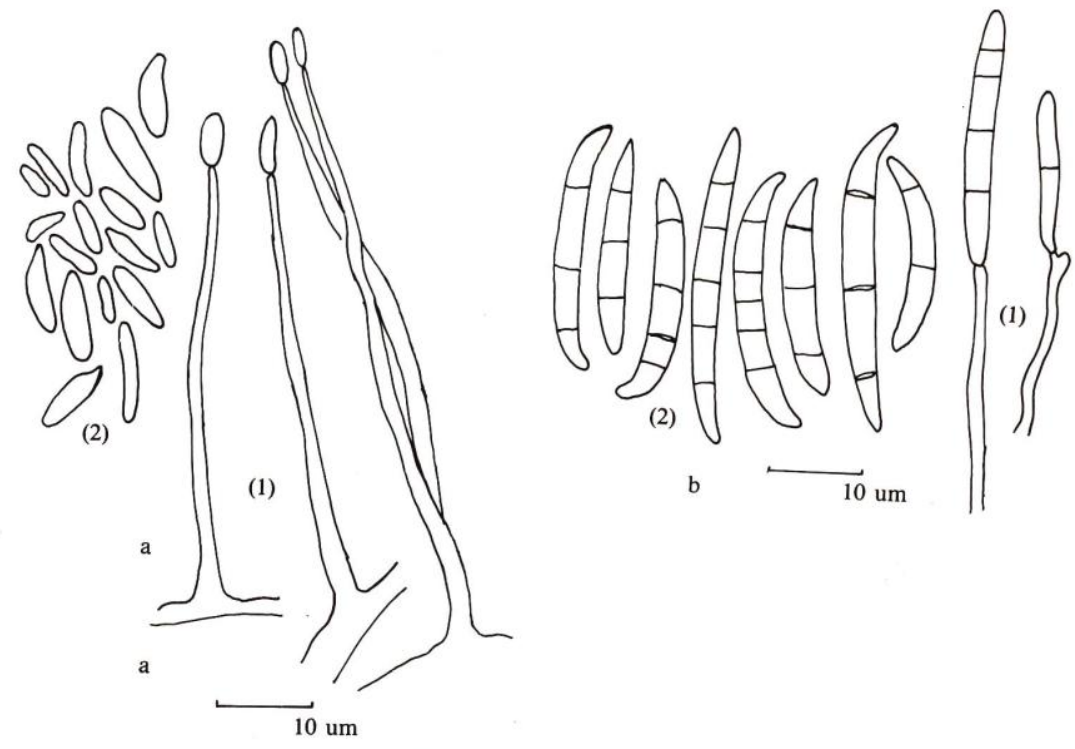

a. (1) microconidiophore, (2) microconidia

b. (1) macroconidiophores, (2) macroconidia

Figure 8. Fusarium sp.1 


\section{Associated fungi}

A secondary parasite, Cylindrocladium sp., was cultured from collar with this Fusarium sp.

\section{Fusarium sp.2}

\section{Host}

Shorea javanica K. \& V.

This other Fusarium sp. was collected on saplings of $25 \mathrm{~cm}$ height, at Krui (Figure 1c).

\section{Symptoms observed in the field}

Defoliation and weathering of the plant was noted with bark darkish in appearance.

\section{Description of the pathogen (Figure 9)}

It was isolated from roots and twigs. The pigmentation of the medium was pink, violet to vinaceous.

The mycelium was violet, vinaceous, cottony and aerial. The growth rate after 4 days was $4.2 \mathrm{~cm}$ (Figure 5).

Microconidiophores were simple phialides or short conidiophores, 21.8-22.4 x $1.6-3.2 \mathrm{um}$. Microconidia were oval, allantoid to oblong. One-celled, they measured 2.6-16.7 x 0.9-3.7 um.

Macroconidia were straight to lightly curved, 2 to 7 septate, measured 10-57.6 x 2-3.5 um, and were produced by short conidiophores.

Chlamydospores were intercalary or terminal to hyphae, simple, of $8.3 \mathrm{x}$ 7.7-9.4 um, double, of 10-14.4 x $6.9 \mathrm{um}$.

\section{Associated fungi}

A secondary parasite, Cylindrocladium sp., was cultured from roots.

\section{Cylindrocarpon destructans (Zinssm.) Scholten, anamorph of Nectrica radicicola}

\section{Hosts}

Shorea pinanga Scheff. and Hopea mengerawan Miq.

$H$. mengerawan was a commercial timber tree of second class value. Seeds of 5. pinanga were collected in the Botanical Garden (Kebun Raya) of Bogor, West Java. 


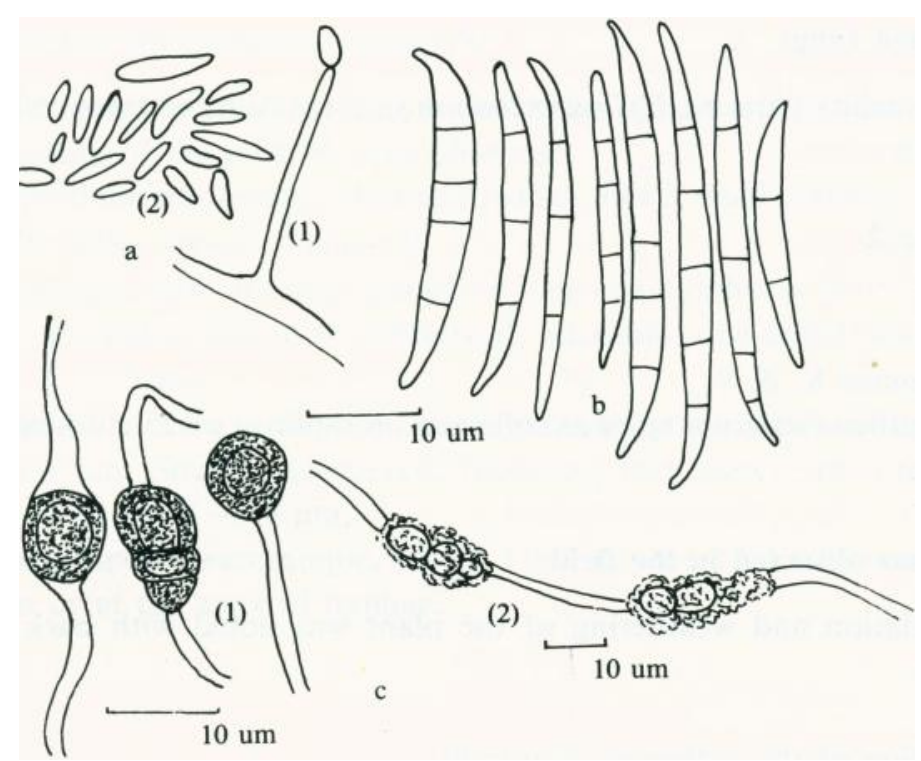
a. microconidiophore and microconidia
b. macroconidia
c. chlamydospores (1) smooth wall, (2) rough wall

Figure 9. Fusarium sp.2

Saplings of $H$. mengerawan were 2 years old and were collected at the experimental plantation of Benakat, near Palembang in South Sumatra (Figure Id).

\section{Symptoms observed in the field (Figures $10 \& 11$ )}

Necrosis and weathering of the seeds of 5. pinanga were observed.

The saplings of $H$. mengerawan had brown spots on leaves delimited by dark lines. The spots first appeared at the apex of the leaf but they covered little by little the entire surface causing the leaf to fall. Thus, photosynthesis activity decreased or stopped leading to the weathering of the host.

\section{Description of the parasite (Figure 12)}

C. destructans was isolated from cotyledons of S. pinanga and was responsible for damping-off. It was also cultured from roots and twigs of sapling of $H$. mengerawan. The pigmentation of the medium was brown to vinaceous.

The mycelium was cream-coloured, violet to violet-grey, layer on medium in small cushion or powdery. The growth rate after 4 days was more than $4 \mathrm{~cm}$ (Figure 3). 
Notes on some Fusarium and Cylindrocarpon -C. Elouard

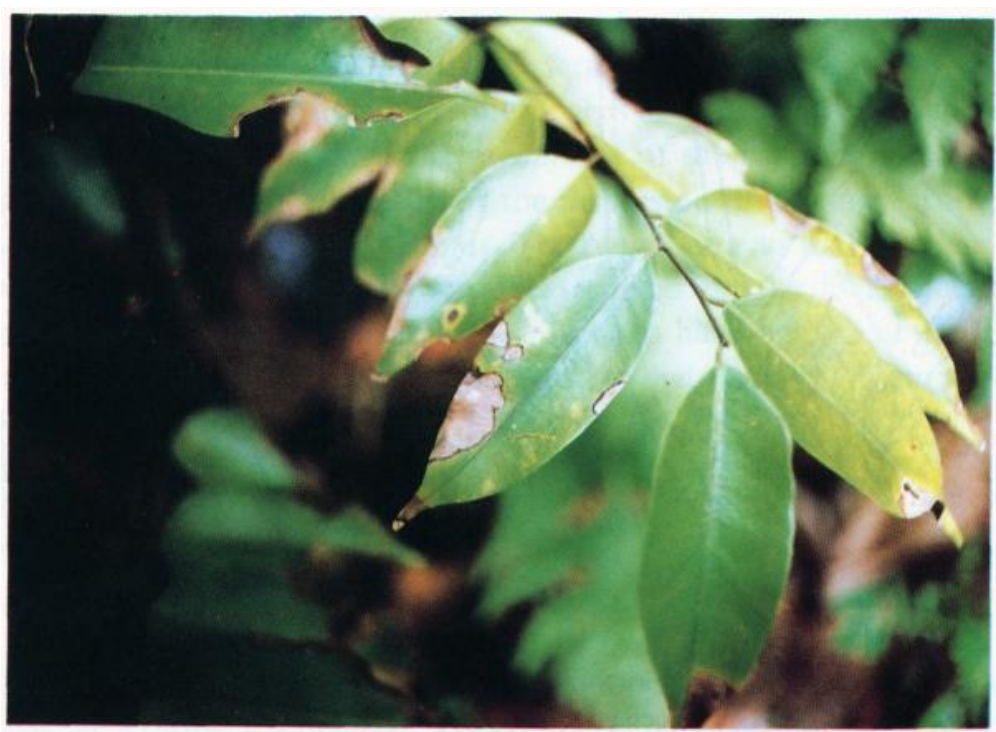

Figure 10. Spots on leaves of Hopea mengerawan caused by Cylindrocarpon destructans.

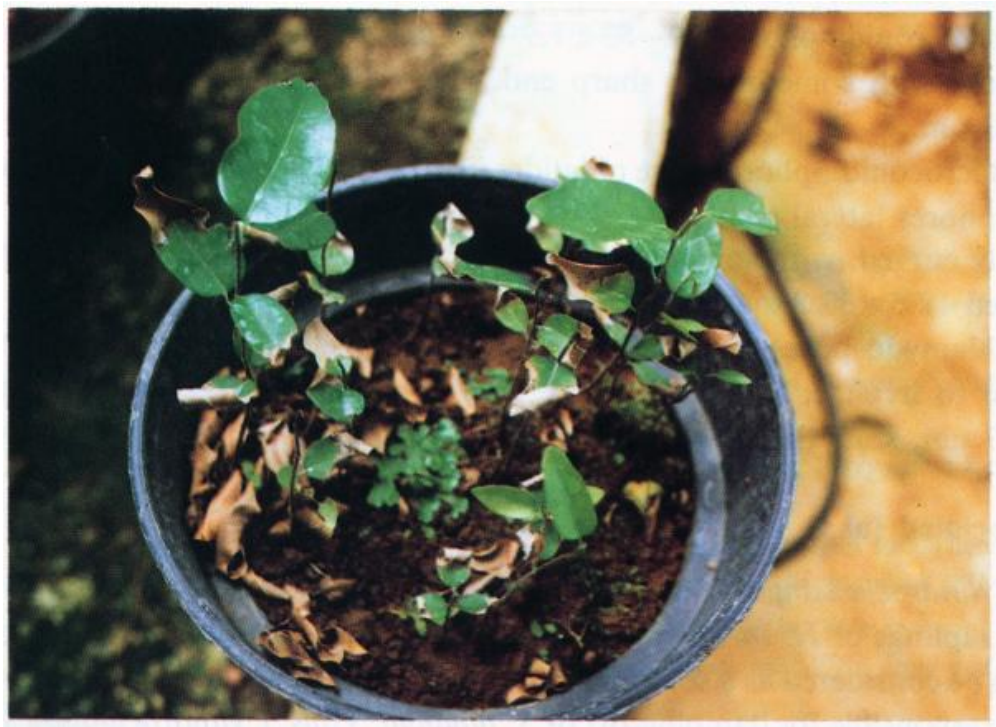

Figure 11. Hopea mengerawan inoculated with Cylindrocarpon destructans. 


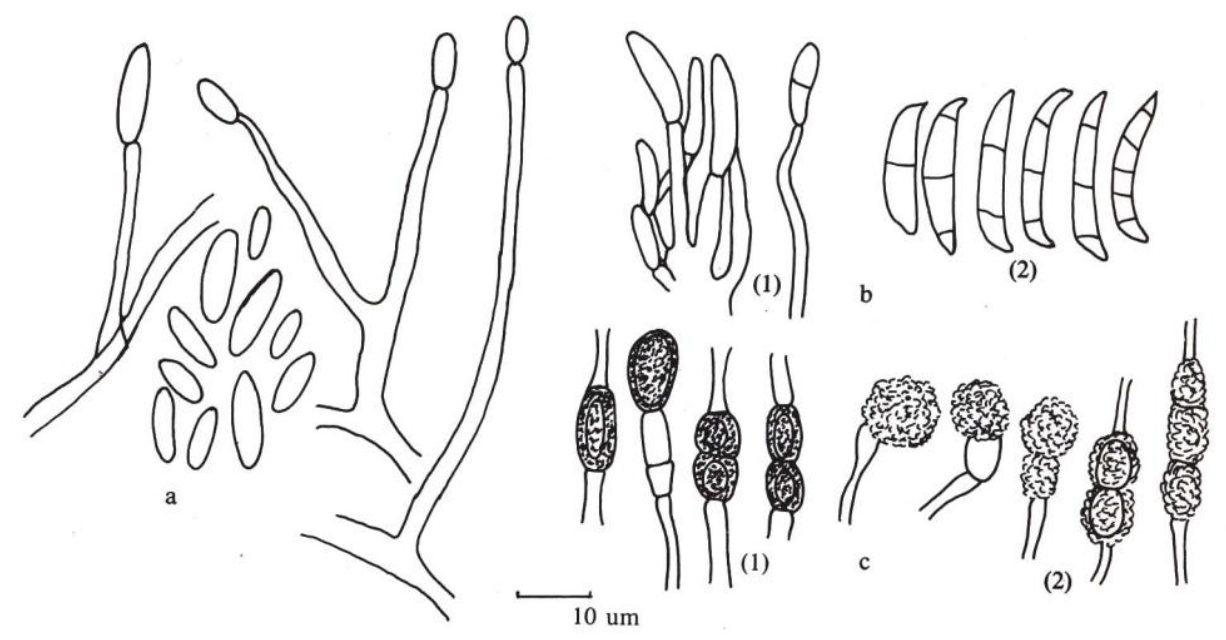

a. phialides, conidiophores and microconidia

b. (1) macroconidiophores, (2) macroconidia

c. chlamydospores (1) smooth wall, (2) rough wall

Figure 12. Cylindrocarpon destructans

Microconidiophores were simple phialides, lateral to hyphae, 8 - 17 × $1.5 \mathrm{um}$, or branched conidiophores, 29 - 83 x 1.7 - 2.7 um. Microconidia were oval, allantoid to oblong, with sometimes a sharp end. One-celled, they measured 5.4-21.2 x 1.8-4.8 um.

Macroconidiophores were phialides in groups, $13-17 \times 2.4-3$ um, or simple conidiophores lateral to hyphae, $27 \times 2 \mathrm{um}$. Macroconidia were thick-set straight to lightly curved, with sometimes curved ends. Most of them were 3 septate and measured 18.5-33.3 x 3.5-5.2 um.

Chlamydospores were both conidial and mycelial; abundant, intercalary or terminal to hyphae; simple, 7-11 x 5-9 um, double 12-16 x 6.9 um, triple 21 x 7.7 um, smooth and rough walled.

\section{Associated fungi}

Cylindrocladium sp. was associated with C. destructans on seeds of S. pinanga and on saplings of $H$. mengerawan. It was isolated from roots of $H$. mengerawan and can be considered as a secondary parasite. On the other hand, Cylindrocladium sp. was responsible for damping-off of $S$. pinanga. Thus, Cylindrocladium sp. seems to be easily associated with $C$. destructans. 


\section{CONCLUSION}

These few observations showed that Fusarium and Cylindrocarpon were not infrequent as disease agents of young Dipterocarps and their attacks very often end in death of the infected plants. If the prevalence of the fungi in natural stands is probably of less importance because of the dispersion of saplings, it may not be the same in nurseries and planted stands. The fungal attacks may become harmful on account of the heavy density of susceptible seedlings and the disease could develop at an epidemic proportion. Thus, it is necessary to have better knowledge of the biology and the ecology of these pathogens, to help prevent their damages in artificial forest stands.

\section{ACKNOWLEDGMENTS}

This workisapartof aresearch programme supported by agrant from the French "Ministere des Affaires Etrangeres". I want to express all my thanks to the Director, Prof. Dr. H. Sitti Soetarmi Tjitrosomo, the Deputy Director, Dr. R. Umaly and to the staff of BIOTROP, particularly to Dr. Okky S. Dharmaputra, for the help they provided me, and to Dr. M.F. Roquebert, Laboratoire de Cryptogamie, Museum d'Histoire Naturelle, Paris, for her invaluable assistance in the identification of Fusarium and Cylindrocarpon specimens.

\section{REFERENCES}

ASHTON, P.S. 1982. Dipterocarpaceae. Flora Malesiana, Series I, Spermatophyta, Flowering Plants, Vol. 9, part 2. p. 552.

BARNETT, H.L. and B.B. HUNTER 1972. Illustrated genera of imperfect fungi. Burgers Publishing Company, third edition, $241 \mathrm{p}$.

воОтн, С. 1971. The genus Fusarium. Commonwealth Mycological Institute, Ferry Lane, Kew, Surrey, England. $237 \mathrm{p}$.

MICHON, G. 1985. De I'homme de la foret au paysan de 1'arbre; agroforesteries Indonsiennes. These de Doctorat, Universit des Sciences et Techniques du Languedoc, Montpellier. 273 p.

NIRENBERG, H. 1976. Untersuchungen liber die morphologishe und biologishe Differenzierung in der Fusarium Section Liseola. Mitteilungen aus der Biologishen Bunderanstalt fur Land und Forstwirt-schaft. Berlin. Dahlem. 117 p. 
RENARD, J.L., J.P. GASCON ET A. BACHY. DEC. 1972. Recherches sur la fusariose du palmier a huile-Research on vascular wilt disease of the oil palm. Oleagineux, $27^{\circ}$ annee, No. 12, pp. 581 - 591.

SYMINGTON, C.F. 1974. Foresters' manual of Dipterocarps. Malayan Forest Record No. 16. University Malaya, Kuala Lumpur, Malaysia. 114 text-fig., 114 planches, 244 p.

TORQUEBIAU, E. 1984. Man-made Dipterocarp Forest in Sumatra Agroforestry Systems 2(2), pp. 103-128. 